\title{
Terrestrial ecosystems response to future changes in climate and atmospheric $\mathrm{CO}_{2}$ concentration
}

\author{
V. K. Arora and G. J. Boer \\ Canadian Centre for Climate Modelling and Analysis, Environment Canada, Victoria, BC, V8W 2Y2, Canada \\ Correspondence to: V. K. Arora (vivek.arora@ec.gc.ca)
}

Received: 15 January 2014 - Published in Biogeosciences Discuss.: 5 March 2014

Revised: 9 June 2014 - Accepted: 29 June 2014 - Published: 8 August 2014

\begin{abstract}
The response of the terrestrial carbon cycle to future changes in climate and atmospheric $\mathrm{CO}_{2}$ is assessed by analysing simulation results for the 2006-2100 period made with the second generation Canadian Earth system model (CanESM2) for the RCP 2.6, RCP 4.5 and RCP 8.5 climate change scenarios. Our interest is in the extent to which global terrestrial carbon pools and sinks, in particular those of the Amazonian region, are vulnerable to the adverse effects of climate change. CanESM2 results indicate that land remains an overall sink of atmospheric carbon for the 2006-2100 period. The net carbon uptake by land in response to changes in climate and atmospheric $\mathrm{CO}_{2}$ is close to 20,80 and $140 \mathrm{Pg} \mathrm{C}$ for the RCP 2.6, 4.5 and 8.5 scenarios, respectively. The latitudinal structure of future atmosphere-land $\mathrm{CO}_{2}$ flux remains similar to that observed for the historical period with northern mid- to high-latitude regions gaining carbon from the atmosphere while the tropics remain either carbon neutral or a modest source of atmospheric carbon depending on scenario. These changes occur in conjunction with simulated precipitation and soil moisture increases over northern mid- and high-latitude land regions and precipitation and soil moisture decreases over the South American continent in all scenarios. Compared to other regions of the globe, which are either carbon sinks or near neutral, the Amazonian region is simulated to be a net source of carbon during the 21 st century. Moreover, and unexpectedly, the rate of carbon loss to the atmosphere from the Amazonian region is largely independent of the differences between the three scenarios considered.
\end{abstract}

\section{Introduction}

The uptake of carbon dioxide by the land and ocean since the start of the industrial era has moderated the rate of increase of atmospheric $\mathrm{CO}_{2}$ that would have otherwise occurred as a consequence of anthropogenic fossil fuel and land use change emissions (Canadell et al., 2007; Le Quéré et al., 2013). Had the land and ocean not provided this "service", all of the emitted $\mathrm{CO}_{2}$ would have stayed in the atmosphere and the atmospheric $\mathrm{CO}_{2}$ concentration would be much higher. Several lines of evidence indicate that northern mid- to high-latitude land regions are sinks of atmospheric carbon at present while tropical land is either carbon neutral or a net source of carbon to the atmosphere (Denman et al., 2007; Ciais et al., 2010; Malhi, 2010; Pan et al., 2011). Terrestrial ecosystems will respond to future changes in climate as well as to changes in atmospheric $\mathrm{CO}_{2}$ concentration, nitrogen deposition rates, and anthropogenic land use change (LUC). The manner and extent to which the land and the ocean will moderate future atmospheric $\mathrm{CO}_{2}$ increase is of scientific and policy relevance.

Earth system models (ESMs), which include representations of terrestrial and oceanic carbon cycle processes, provide a tool with which to study the response of terrestrial ecosystems to possible future changes in climate and atmospheric $\mathrm{CO}_{2}$ concentration. We analyse results from simulations made with the second generation Canadian Earth system model (CanESM2) in order to investigate terrestrial ecosystem response to the changes in climate and atmospheric $\mathrm{CO}_{2}$ concentration consistent with three future climate change scenarios. Our interest is in the extent to which terrestrial ecosystems are able to function as sinks of atmospheric carbon. The simulations analysed here are a contribution to the fifth Coupled Model Intercomparison 
Project (CMIP5, http://cmip-pcmdi.llnl.gov/cmip5/forcing. html) (Taylor et al., 2012) and the fifth assessment report (AR5) of the Intergovernmental Panel on Climate Change (IPCC). Simulations results are based on three representative concentration pathway (RCP) scenarios, RCP 2.6, 4.5 and 8.5 (Moss et al., 2010), for the period 2006-2100.

We focus on the behaviour of the terrestrial carbon cycle in general and on the Amazonian region in particular where the simulated reduction in precipitation transforms the region from a sink of atmospheric carbon over the historical period to a source of atmospheric carbon during the 21 st century.

\section{Model description and experimental set up}

CanESM2 has evolved from the first generation Canadian ESM (CanESM1) (Arora et al., 2009; Christian et al., 2010) of the Canadian Centre for Climate Modelling and Analysis (CCCma) as described in detail in Arora et al. (2011). Its fourth generation atmospheric component (CanAM4) has evolved from CCCma's third generation atmospheric general circulation model (Scinocca et al., 2008). CanAM4 is a spectral model employing T63 triangular truncation with physical tendencies calculated on a $128 \times 64\left(\sim 2.81^{\circ}\right)$ horizontal linear grid, and 35 layers in the vertical whose thicknesses increase monotonically with height to $1 \mathrm{hPa}$. The physical ocean component of CanESM2 has 40 levels with approximately $10 \mathrm{~m}$ resolution in the upper ocean and the horizontal ocean resolution is approximately $1.41^{\circ}$ (longitude) $\times 0.94^{\circ}$ (latitude).

The ocean and land carbon cycle components of CanESM2 are represented by the Canadian Model of Ocean Carbon (CMOC) (Christian et al., 2010) and the Canadian Terrestrial Ecosystem Model (CTEM) (Arora et al., 2009; Arora and Boer, 2010), respectively. LUC emissions are modelled interactively on the basis of changes in land cover, if prescribed, that are determined by changes in crop area. The historical land cover is reconstructed using the linear approach of Arora and Boer (2010); as the fraction of crop area in a grid cell changes the fraction of non-crop plant functional types (PFTs) is adjusted linearly in proportion to their existing coverage. The historical changes in crop area are based on the data set provided for CMIP5 simulations. When fraction of crop area in a grid cell increases then the fractional coverage of other PFTs is reduced which results in deforested biomass. The deforested biomass is allocated to three components that are burned instantaneously and contribute to short and long term wood product pools (Arora and Boer, 2010). When the fraction of crop area decreases, the fractional coverage of non-crop PFTs increases and their vegetation biomass is spread over a larger area reducing vegetation density. Carbon is sequestered until a new equilibrium is reached providing a carbon sink associated with regrowth as the abandoned areas revert back to natural vegetation.

A comparison of the simulated 20th century carbon budget in CanESM2 with observation-based estimates is given in Arora et al. (2011) together with an analysis of globally averaged carbon budget quantities for the 21 st century. Here, we focus on the zonal and geographical distribution of the simulated cumulative atmosphere-land $\mathrm{CO}_{2}$ flux and on the changes in live vegetation biomass and dead organic carbon pools over the 21st century.

An ensemble of three simulations for 2006-2100, for each of the RCPs, are continuations of 1850-2005 historical simulations as explained in Arora et al. (2011). In these historical and future simulations the atmospheric concentrations of $\mathrm{CO}_{2}$ and other greenhouse gases (GHGs) are specified. The historical simulations are forced by anthropogenic changes in atmospheric concentration of $\mathrm{CO}_{2}$ and non- $\mathrm{CO}_{2}$ greenhouse gases, emissions of aerosols, and land cover as well as by natural solar variability and volcanic aerosols. As a result, over the historical period, land use change (LUC) affects the simulated climate through biogeophysical feedbacks associated with increase in crop area and the simulated atmosphere-land $\mathrm{CO}_{2}$ flux through treatment of interactive LUC emissions. The simulations for 2006-2100 are forced with changes in $\mathrm{CO}_{2}$, non- $\mathrm{CO}_{2}$ GHGs and aerosols following the RCP scenarios. However, the land cover in these future simulations is held fixed at its 2005 value so that the terrestrial biosphere responds only to changes in climate and atmospheric $\mathrm{CO}_{2}$ concentration, except that the year 2005 land cover is the result of changes in crop area over the historical period. Unlike the historical simulations, anthropogenic LUC in future simulations does not affect the simulated atmosphere-land $\mathrm{CO}_{2}$ flux.

Solar variability is included by repeating the 1997-2008 solar cycle. These simulations, without future anthropogenic land use change, are also a contribution to the LUCIDCMIP5 (Land-Use and Climate, IDentification of robust impacts) intercomparison that focuses on biophysical and biogeochemical effects of LUC in CMIP5 simulations (Brovkin et al., 2013).

\section{Carbon budget equations}

\subsection{Vertically integrated equations}

The vertically integrated carbon budget equation for the atmosphere and the underlying land and ocean are written as

$$
\begin{aligned}
\frac{\mathrm{d} h_{\mathrm{A}}}{\mathrm{d} t} & =A_{\mathrm{A}}-\left(f_{\mathrm{O}}+f_{\mathrm{L}}\right)+e_{\mathrm{F}}=A_{\mathrm{A}}-\left(f_{\mathrm{O}}+f_{1}\right)+\left(e_{\mathrm{F}}+e_{\mathrm{L}}\right) \\
\frac{\mathrm{d} h_{\mathrm{O}}}{\mathrm{d} t} & =A_{\mathrm{O}}+f_{\mathrm{O}} \\
\frac{\mathrm{d} h_{\mathrm{L}}}{\mathrm{d} t} & =f_{\mathrm{L}}=f_{1}-e_{\mathrm{L}}=\frac{\mathrm{d} h_{1}}{\mathrm{~d} t}-e_{\mathrm{L}} \\
& =\frac{\mathrm{d} h_{\mathrm{V}}}{\mathrm{d} t}+\frac{\mathrm{d} h_{\mathrm{S}}}{\mathrm{d} t}=f_{1}-e_{\mathrm{L}}=n-r_{\mathrm{H}}-e_{\mathrm{L}}
\end{aligned}
$$


with the carbon budget equation for the entire system written

as

$$
\frac{\mathrm{d} h}{\mathrm{~d} t}=\frac{\mathrm{d} h_{\mathrm{A}}}{\mathrm{d} t}+\frac{\mathrm{d} h_{\mathrm{O}}}{\mathrm{d} t}+\frac{\mathrm{d} h_{\mathrm{L}}}{\mathrm{d} t}=\left(A_{\mathrm{A}}+A_{\mathrm{O}}\right)+e_{\mathrm{F}}=A+e_{\mathrm{F}} .
$$

Here $h=h_{\mathrm{A}}+h_{\mathrm{O}}+h_{\mathrm{L}}$ is the total carbon content $\left(\mathrm{g} \mathrm{C} \mathrm{m}^{-2}\right)$ of the atmosphere, ocean and land respectively, $A_{\mathrm{A}}$ and $A_{\mathrm{O}}$ the carbon transports by the atmosphere and ocean $\left(\mathrm{g} \mathrm{C} \mathrm{m}^{-2} \mathrm{yr}^{-1}\right)$ and $A$ their sum, $f_{\mathrm{O}}$ and $f_{\mathrm{L}}$ are atmosphereocean and atmosphere-land $\mathrm{CO}_{2}$ fluxes $\left(\mathrm{g} \mathrm{C} \mathrm{m}^{-2} \mathrm{yr}^{-1}\right)$ and $e_{\mathrm{F}}$ is the local anthropogenic fossil fuel emission rate $\left(\mathrm{g} \mathrm{C} \mathrm{m}^{-2} \mathrm{yr}^{-1}\right)$.

The net atmosphere-land $\mathrm{CO}_{2}$ flux $f_{\mathrm{L}}=f_{1}-e_{\mathrm{L}}$ partakes of both the carbon released into the atmosphere due to LUC, expressed here as an emission rate $e_{\mathrm{L}}$, as well as the remaining "natural" $\mathrm{CO}_{2}$ flux $f_{1}$ not associated with LUC. $f_{1}$ is also referred to as the residual land sink in the context of the historical carbon budget (Le Quéré et al., 2013). The rate of change of land carbon associated with this flux is $\mathrm{d} h_{1} / \mathrm{d} t=f_{1}$. In Eq. (1) the land carbon $h_{\mathrm{L}}=h_{\mathrm{V}}+h_{\mathrm{S}}$ is composed of live vegetation biomass $h_{\mathrm{V}}\left(\mathrm{g} \mathrm{C} \mathrm{m}^{-2}\right)$ and dead organic carbon $h_{\mathrm{S}}\left(\mathrm{g} \mathrm{C} \mathrm{m}^{-2}\right)$ in the soil and litter carbon pools. $f_{1}=n-r_{\mathrm{H}}\left(\mathrm{g} \mathrm{C} \mathrm{m}^{-2} \mathrm{yr}^{-1}\right)$ is the difference between local values of terrestrial net primary productivity (NPP) and heterotrophic respiration. Fire is not operating in these CanESM2 simulations.

\subsection{Globally integrated equations}

In the model, values are known on the model grid. For grid values $x_{i j}$ in Eqs. (1) and (2) (where $i$ and $j$ identify grid squares centred at longitude $\lambda_{i}$ and latitude $\phi_{j}$ ) the integrated global value is

$$
\begin{aligned}
X & =\iint x R^{2} \cos \phi d \lambda d \phi=\sum_{i j} x_{i j} \Delta \sigma_{i j} \\
& =\sum_{j}\left(\sum_{i} x_{i j} \Delta \sigma_{i j}\right)=\sum_{j}[x]_{j},
\end{aligned}
$$

where $R$ is the radius of the Earth and $\Delta \sigma_{i j}$ the grid cell area. Here $[x]$ is the contribution to the global value from a latitudinal band.

The transport terms $\left(A, A_{\mathrm{A}}, A_{\mathrm{O}}\right)$ go to zero when integrated over the globe and the resulting equations for the net carbon in system components parallel those in Eq. (1) with

$$
\begin{aligned}
\frac{\mathrm{d} H_{\mathrm{A}}}{\mathrm{d} t} & =-\left(F_{\mathrm{O}}+F_{\mathrm{L}}\right)+E_{\mathrm{F}}=-\left(F_{\mathrm{O}}+F_{1}\right)+\left(E_{\mathrm{F}}+E_{\mathrm{L}}\right) \\
\frac{\mathrm{d} H_{\mathrm{O}}}{\mathrm{d} t} & =F_{\mathrm{O}} \\
\frac{\mathrm{d} H_{\mathrm{L}}}{\mathrm{d} t} & =F_{\mathrm{L}}=F_{1}-E_{\mathrm{L}}=\frac{\mathrm{d} H_{1}}{\mathrm{~d} t}-E_{\mathrm{L}} \\
& =\frac{\mathrm{d} H_{\mathrm{V}}}{\mathrm{d} t}+\frac{\mathrm{d} H_{\mathrm{S}}}{\mathrm{d} t}=F_{1}-E_{\mathrm{L}}=N-R_{\mathrm{H}}-E_{\mathrm{L}}
\end{aligned}
$$

$$
\begin{aligned}
\frac{\mathrm{d} H_{1}}{\mathrm{~d} t} & =F_{1} \\
\frac{\mathrm{d} H}{\mathrm{~d} t} & =E_{\mathrm{F}} .
\end{aligned}
$$

Similar to Eq. (2), $H=H_{\mathrm{A}}+H_{\mathrm{O}}+H_{\mathrm{L}}$ is the global carbon content $(\mathrm{PgC})$ of the atmosphere, ocean and land respectively. $F_{\mathrm{O}}$ and $F_{\mathrm{L}}$ are global atmosphere-ocean and atmosphere-land $\mathrm{CO}_{2}$ fluxes $\left(\mathrm{Pg} \mathrm{C} \mathrm{yr}^{-1}\right)$ and $E_{\mathrm{F}}$ is the

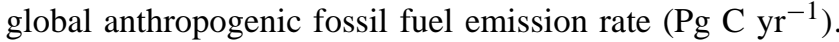
$F_{\mathrm{L}}=F_{1}-E_{\mathrm{L}}$ is composed of global LUC emission rate $E_{\mathrm{L}}$ as well as the remaining global "natural" $\mathrm{CO}_{2}$ flux $F_{1}$. Finally, $N$ and $R_{\mathrm{H}}$ are global net primary productivity and heterotrophic respiration $\left(\mathrm{Pg} \mathrm{C} \mathrm{yr}^{-1}\right)$. Here, $E_{\mathrm{L}}$ is positive for historical simulations which account for changes in land cover over the historical period, but zero for future simulations.

Integrating Eq. (4) in time with $\int_{t_{0}}^{t}(\mathrm{~d} H / \mathrm{d} t) \mathrm{d} t=H(t)-$ $H\left(t_{0}\right)=\Delta H(t)$ and $\int_{t_{0}}^{t} F \mathrm{~d} t=\tilde{F}(t)(\mathrm{PgC})$ gives

$$
\begin{aligned}
\Delta H_{\mathrm{A}} & =-\left(\tilde{F}_{\mathrm{O}}+\tilde{F}_{1}\right)+\left(\tilde{E}_{\mathrm{F}}+\tilde{E}_{\mathrm{L}}\right) \\
\Delta H_{\mathrm{O}} & =\tilde{F}_{\mathrm{O}} \\
\Delta H_{\mathrm{L}} & =\tilde{F}_{\mathrm{L}}=\tilde{F}_{1}-\tilde{E}_{\mathrm{L}} ; \\
& =\Delta H_{\mathrm{V}}+\Delta H_{\mathrm{S}}=\tilde{F}_{1}-\tilde{E}_{\mathrm{L}}=\tilde{N}-\tilde{R}_{\mathrm{H}}-\tilde{E}_{\mathrm{L}} \\
\Delta H_{\mathrm{l}} & =\tilde{F}_{1} \\
\Delta H & =\tilde{E}_{\mathrm{F}} .
\end{aligned}
$$

The cumulative change of carbon in the atmosphere, the ocean and the land carbon not associated with LUC is

$\Delta H_{\mathrm{A}}+\Delta H_{\mathrm{O}}+\Delta H_{1}=\tilde{E}_{\mathrm{F}}+\tilde{E}_{\mathrm{L}}=\tilde{E}$,

where $\tilde{E}(\operatorname{PgC})$ is the sum of the anthropogenic emissions from fossil fuel consumption and land use change. Finally, dividing Eq. (6) by $\tilde{E}$ gives

$\Phi_{\mathrm{A}}+\Phi_{\mathrm{O}}+\Phi_{1}=\frac{\Delta H_{\mathrm{A}}}{\tilde{E}}+\frac{\Delta H_{\mathrm{O}}}{\tilde{E}}+\frac{\Delta H_{1}}{\tilde{E}}=1$,

the fractions of anthropogenic emissions remaining in the atmosphere (the airborne fraction) and taken up by the ocean and land over the period.

The local contribution $\varphi$ to the global fraction of emissions taken up by land follows from

$$
\begin{aligned}
\Phi_{1} & =\frac{\Delta H_{1}}{\tilde{E}}=\iint \frac{\Delta h_{1}}{\tilde{E}} d \sigma=\sum_{i j} \frac{\Delta h_{l, i j} \Delta \sigma_{i j}}{\tilde{E}} \\
& =\sum_{i j} \varphi_{i j}=\sum_{j}[\varphi]_{j},
\end{aligned}
$$

where $\varphi$ (dimensionless) is the ratio of the local change in land carbon $\Delta h_{1}$ to total global anthropogenic emissions $\tilde{E}$. 
From Eq. (8), $\varphi_{i j}$ and $[\varphi]_{j}$ are, respectively, the contribution of a grid cell and a latitudinal band to $\Phi_{1}$.

We consider a further local metric that quantifies the response or "reactivity" of land carbon change to the changes in climate and $\mathrm{CO}_{2}$ associated with the different scenarios. The difference in the local land carbon change, over the 2006-2100 period, between the most strongly (RCP 8.5) and least strongly (RCP 2.6) forced scenarios $\left(\Delta h_{1(8.5)}-\right.$ $\left.\Delta h_{1(2.6)}\right)$ is compared to the change $\Delta h_{1(4.5)}$ for the "moderately" forced scenario RCP 4.5. The reactivity of land carbon change (dimensionless) in this case is

$\vartheta=\frac{\left|\Delta h_{1(8.5)}-\Delta h_{1(2.6)}\right|}{\left|\Delta h_{1(4.5)}\right|}$.

This characterization, as the ratio of the range over the median change, could be more generally applied to a large ensemble of results. Values of $\vartheta$ are greater than one when the spread in land carbon change across scenarios is greater than the median change implying that the land carbon change is responsive to differences in climate change scenarios. Conversely, values of $\vartheta$ less than one imply that land carbon responds comparatively weakly to differences in forcing scenarios.

\section{Results}

\subsection{Globally averaged values}

Figure 1 displays the time series of simulated carbon budget quantities for the three RCP scenarios as well as that of the pre-industrial control case in which atmospheric $\mathrm{CO}_{2}$ concentration is held at $284.7 \mathrm{ppm}$. The shading indicates the range across the three ensemble members for each case. Figure 1a plots the time series of the atmospheric $\mathrm{CO}_{2}$ concentration and Fig. 1b the cumulative global atmosphereland $\mathrm{CO}_{2}$ flux $\tilde{F}_{1}=\Delta H_{1}$ for the period 2006-2100. In the absence of LUC, $\tilde{F}_{\mathrm{L}}=\tilde{f}_{1}$ and $\tilde{H}_{\mathrm{L}}=\tilde{H}_{1}$. Climate is in near equilibrium in the control simulation and its $\tilde{F}_{1}$ values indicate only a very small residual drift $\left(0.052 \mathrm{PgC} \mathrm{yr}^{-1}\right)$. Land is an overall sink of atmospheric carbon in all climate change scenarios with the highest carbon uptake for the RCP 8.5 scenario $(\sim 140 \mathrm{PgC})$ and lowest for the RCP 2.6 scenario ( $\sim 20 \mathrm{PgC}$ ). The higher $\mathrm{CO}_{2}$ concentration in the RCP 8.5 scenario yields higher terrestrial net primary productivity $N$ compared to the RCP 4.5 and 2.6 scenarios (Fig. 1c). The RCP 8.5 scenario also displays higher heterotrophic respiration $R_{\mathrm{H}}$ (Fig. 1d) due to much warmer simulated temperatures over land as well as higher litter fall inputs (through increased NPP) to litter and soil carbon pools. Overall, however, since $R_{\mathrm{H}}$ exceeds litter fall, the combined litter and soil carbon mass decreases over the 21 st century for all scenarios (Fig. 1f) with the largest decrease for the RCP 8.5 scenario. Simulated vegetation biomass $H_{\mathrm{V}}$ (Fig. 1e) exhibits behaviour similar to $R_{\mathrm{H}}$ with the largest (smallest) increase for the RCP 8.5 (2.6) scenario. In all scenarios, the decrease in soil carbon and litter mass $H_{\mathrm{S}}$ (Fig. 1f) is small relative to changes in vegetation biomass $H_{\mathrm{V}}$. The simulated uptake of atmospheric carbon over land is primarily the result of an increase in vegetation biomass.

Figure 2 displays the airborne fraction $\left(\Phi_{\mathrm{A}}\right)$ of cumulative anthropogenic fossil and LUC emissions $\tilde{E}$ and the corresponding fraction of emissions taken up by the land $\left(\Phi_{1}\right)$ and the ocean $\left(\Phi_{O}\right)$ over the 2006-2100 period for the three RCP scenarios. The year 2005 values are based on CanESM2 historical simulations for the 1850-2005 period as described in Arora et al. (2011). The 2005 value of $\Phi_{\mathrm{A}}$ of 0.51 lies towards the upper end of the range $0.34-0.52$ for this quantity estimated from an observation-based increase in atmospheric carbon burden of $200 \mathrm{PgC}$, anthropogenic fossil fuel emissions of $330 \pm 20 \mathrm{Pg} \mathrm{C}$ and LUC emissions of $156 \pm 78 \mathrm{Pg} \mathrm{C}$ from Houghton (2008) (assuming $\pm 50 \%$ uncertainty in LUC emissions) for the period 1850-2005 as discussed in Arora et al. (2011).

In Fig. 2, $\Phi_{\mathrm{A}}$ increases and then decreases for the RCP 2.6 and 4.5 scenarios but continues to increase for the RCP 8.5 scenario in response to a continued increase in atmospheric $\mathrm{CO}_{2}$ concentration (Fig. 1a). The behaviour of $\Phi_{\mathrm{A}}$ in CanESM2 simulations is similar to that of other CMIP5 models as reported in Jones et al. (2013) (their Fig. 7). In the RCP 8.5 scenario, since atmospheric $\mathrm{CO}_{2}$ concentration increases at a faster rate than the capacity of the land and ocean to sequester it, a larger fraction of the emissions stays in the atmosphere and $\Phi_{\mathrm{A}}$ continues to increase.

The fraction $\Phi_{1}$ of cumulative emissions that is taken up by land (Fig. 2b) decreases in all three scenarios. Results for the RCP 2.6 and 4.5 scenarios are similar with a larger decrease in $\Phi_{1}$ seen for the RCP 8.5 scenario. In that scenario especially, the carbon dioxide removal "service" provided by the land in sequestering carbon weakens with time.

By contrast to $\Phi_{1}$, the fraction of the cumulative anthropogenic emissions taken up by the oceans $\Phi_{\mathrm{O}}$ (Fig. 2c) increases in the RCP 2.6 and 4.5 scenarios although it decreases for the RCP 8.5 scenario. On long time scales the oceans are the eventual main reservoirs of anthropogenic carbon owing to their much larger capacity to store carbon compared to the land. Atmospheric $\mathrm{CO}_{2}$ concentration increases more slowly in the RCP 2.6 and 4.5 scenarios than in the RCP 8.5 scenario and the rate of carbon uptake by the oceans more than keeps up with the rate of increase of atmospheric $\mathrm{CO}_{2}$ hence $\Phi_{\mathrm{O}}$ increases and $\Phi_{\mathrm{A}}$ decreases (Fig. 2a and c). In the RCP 8.5 scenario, by contrast, atmospheric $\mathrm{CO}_{2}$ increases at a faster rate than in the RCP 2.6 and 4.5 scenarios and the carbon uptake by the oceans cannot keep up with the increasing atmospheric $\mathrm{CO}_{2}$. The result is decreasing $\Phi_{\mathrm{O}}$ and increasing $\Phi_{\mathrm{A}}$ for the RCP 8.5 scenario.

Interpreted in terms of the "service" of atmospheric $\mathrm{CO}_{2}$ removal that is provided by the oceans and the land, the ocean provides this service at an accelerating rate in the RCP 2.6 and 4.5 scenarios while the service provided by the land 
a) $\mathrm{CO}_{2}(\mathrm{ppm})$

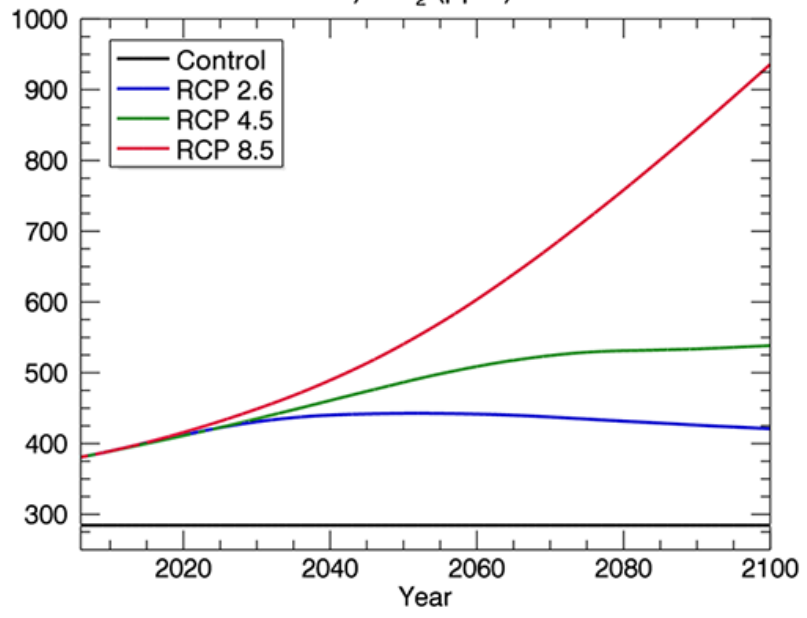

c) Net primary productivity, $\mathrm{N}(\mathrm{Pg} \mathrm{C} / \mathrm{yr})$

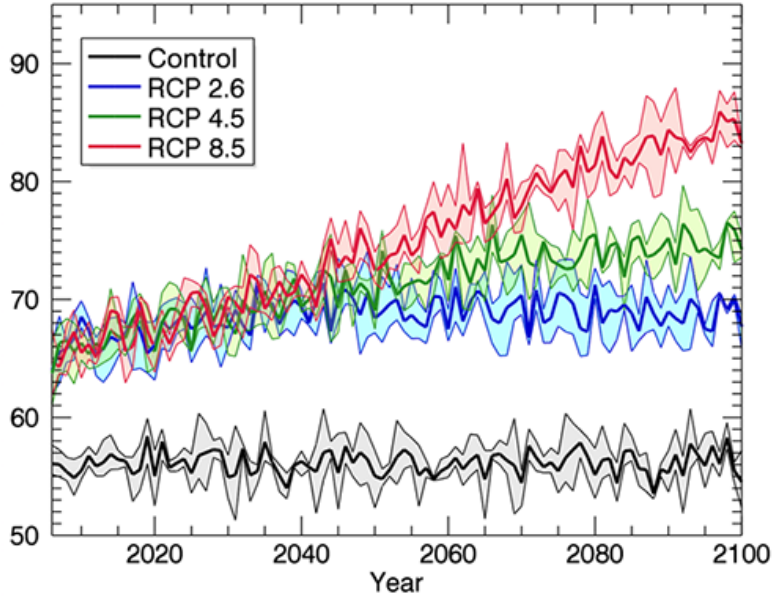

e) Vegetation Biomass, $\mathrm{H}_{\mathrm{v}}(\mathrm{Pg} \mathrm{C})$

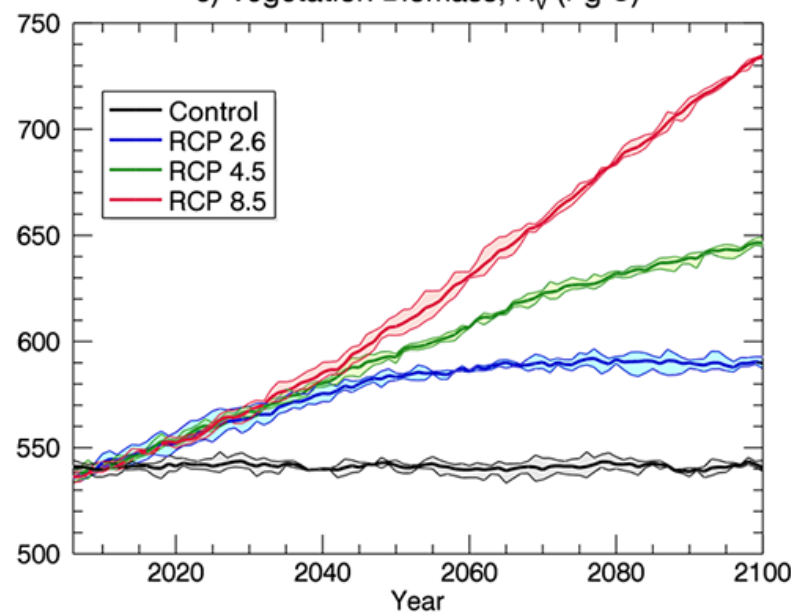

b) Cumulative atmosphere-land $\mathrm{CO}_{2}$ flux, $\overrightarrow{\mathrm{F}}_{1}(\mathrm{Pg} \mathrm{C})$

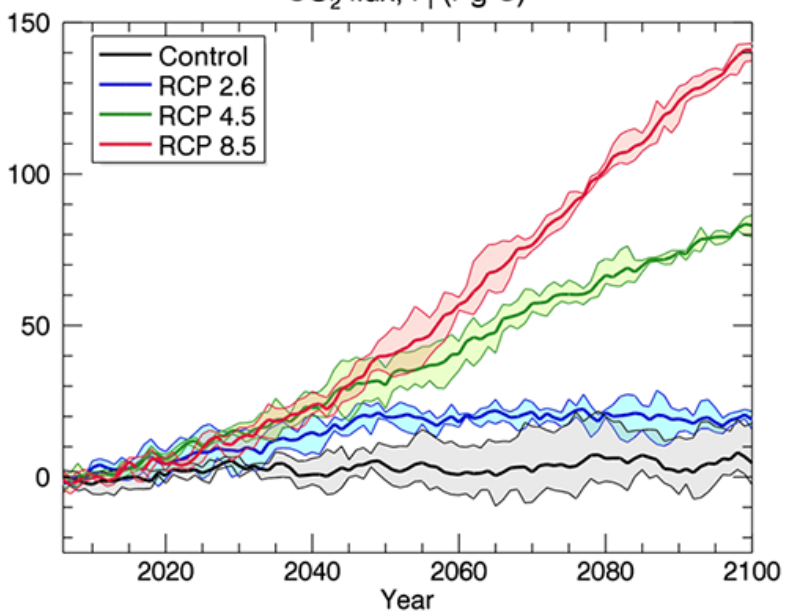

d) Hetrotrophic Respiration, $\mathrm{R}_{\mathrm{H}}(\mathrm{Pg} \mathrm{C} / \mathrm{yr})$

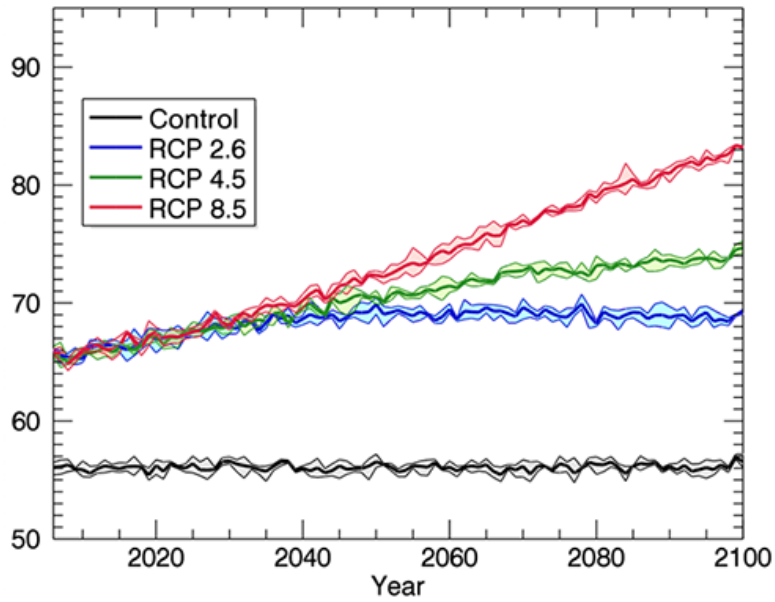

f) Soil and Litter Carbon, $\mathrm{H}_{\mathrm{S}}(\mathrm{Pg} \mathrm{C})$

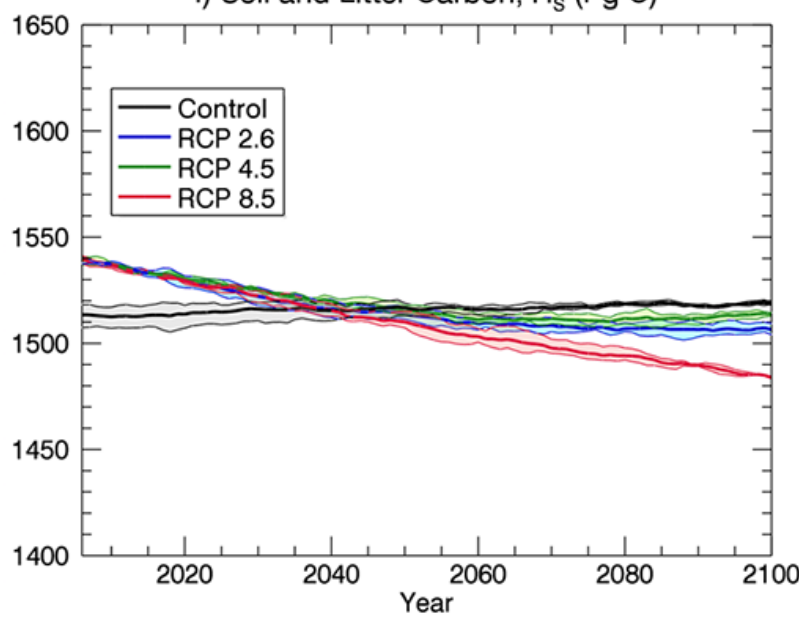

Figure 1. (a) Specified $\mathrm{CO}_{2}$ concentrations used for the pre-industrial control and the three RCP-based simulations; (b) simulated cumulative atmosphere-land $\mathrm{CO}_{2}$ uptake, $\tilde{F}_{1}=\Delta H_{1} ;$ (c) terrestrial net primary productivity, $N ;$ (d) heterotrophic respiration, $R_{\mathrm{H}}$; (e) vegetation biomass, $H_{\mathrm{V}}$; and (f) soil plus litter carbon, $H_{\mathrm{S}}$. The shading indicates the range in the variables across the three ensemble members of the simulations. The $y$-axis range is the same in panels (e) and (f). 
a) Airborne fraction of cumulative emissions

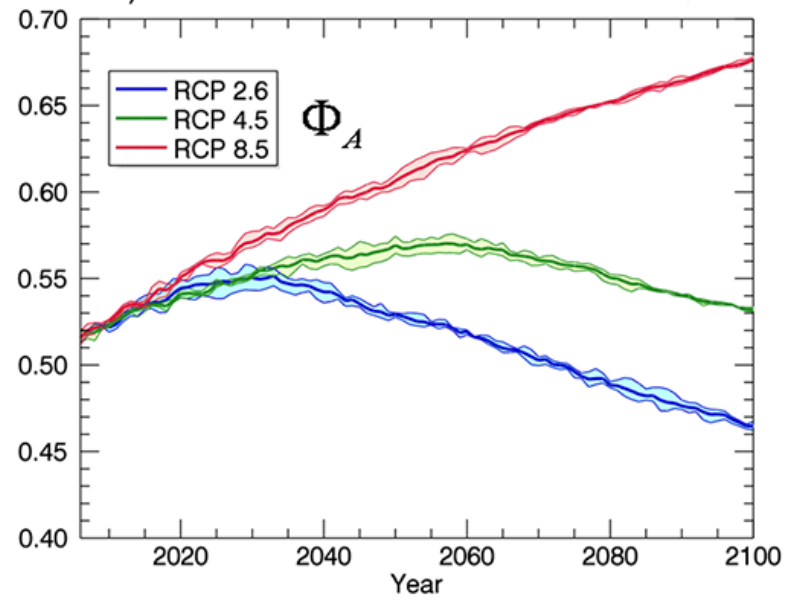

b) Fraction of cumulative emissions taken up by land

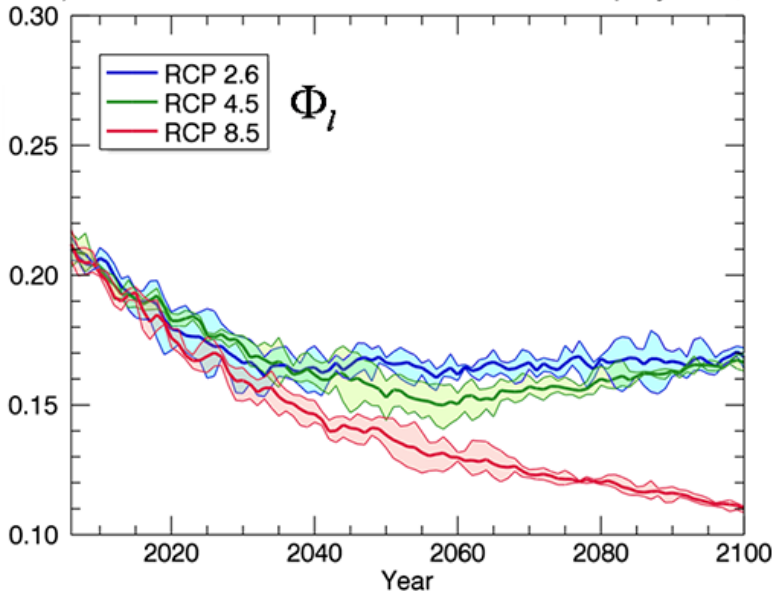

c) Fraction of cumulative emissions taken up by ocean

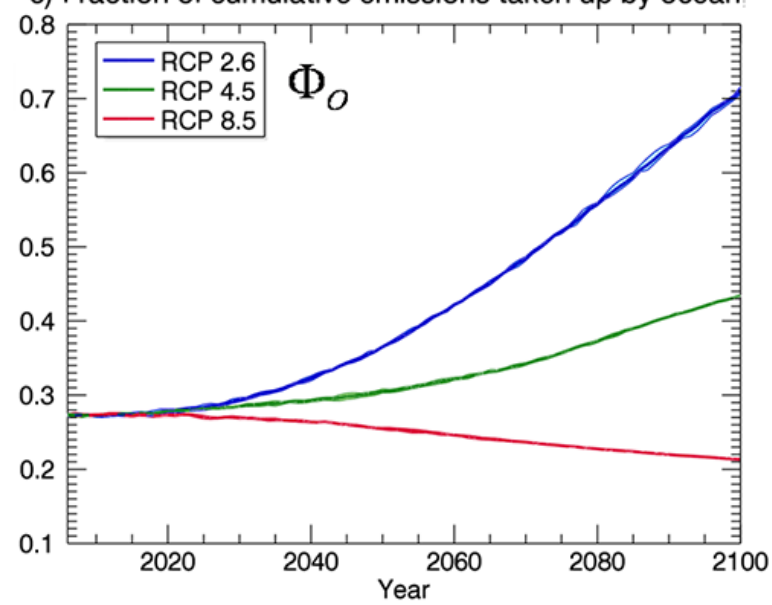

Figure 2. Airborne fraction of cumulative fossil fuel and LUC emissions $\left(\Phi_{\mathrm{A}}, \mathbf{a}\right)$ and fraction of these cumulative emissions taken up by land $\left(\Phi_{1}, \mathbf{b}\right)$ and ocean $\left(\Phi_{\mathrm{O}}, \mathbf{c}\right)$ for the 2006-2100 period and for the three RCP scenarios. The year 2005 values are calculated using results from the CanESM2 historical simulations as reported in Arora et al. (2011).

decreases and then stabilizes. For the more extreme RCP 8.5 scenario, the service provided by both the land and the ocean continues to decline.

\subsection{Latitudinal behaviour}

Figure 3 a plots the latitudinal distribution of $\left[\tilde{f}_{\mathrm{L}}\right]=\left[\tilde{f}_{1}\right]-$ $\left[\tilde{e}_{\mathrm{L}}\right]$, the cumulative net atmosphere-land $\mathrm{CO}_{2}$ flux (grey line) for the historical period 1850-2005 together with the "natural" flux $\left[\tilde{f}_{1}\right]$ excluding LUC emissions (dark line). Both are based on CanESM2's historical simulation as reported in Arora et al. (2011). For the historical period the overall flux $\left[\tilde{f}_{\mathrm{L}}\right]$ evidences a loss of carbon from land between 30 and $55^{\circ} \mathrm{N}$ because of the LUC emissions $e_{\mathrm{L}}$ associated with the expansion of cropland during the period, approximated here to first order as deforested biomass. The natural flux $\left[\tilde{f}_{1}\right]$, by contrast, is positive at all latitudes. $\mathrm{Cu}-$ mulative values $\left[\tilde{f}_{\mathrm{L}}\right]$ in Fig. 3a for the historical 1850-2005 period are in broad agreement with the consensus that carbon uptake has been occurring in northern mid- to high-latitude regions while the tropics are, on average, near neutral or a small source of carbon to the atmosphere (Denman et al., 2007; Ciais et al., 2010; Malhi, 2010; Pan et al., 2011).

The distributions of $\left[\tilde{f}_{1}\right]$ for 2006-2100 (which are also the distributions of $\left[\tilde{f}_{\mathrm{L}}\right]$ in these simulations of future climate), are shown in Fig. $3 \mathrm{~b}$ for the three RCP scenarios. The latitudinal structures of $\left[\tilde{f}_{1}\right]$ are similar to one another for the three climate change scenarios and for the historical period in Fig. 3a at mid- to high-latitudes where land gains carbon from the atmosphere in the absence of LUC emissions. The scenario fluxes for the tropical region (between $30^{\circ} \mathrm{S}$ and $30^{\circ} \mathrm{N}$ ) indicates a moderate carbon loss in the RCP 2.6 scenario, but near-neutral carbon exchange in the RCP 4.5 and 8.5 scenarios, because the $\mathrm{CO}_{2}$ fertilization 

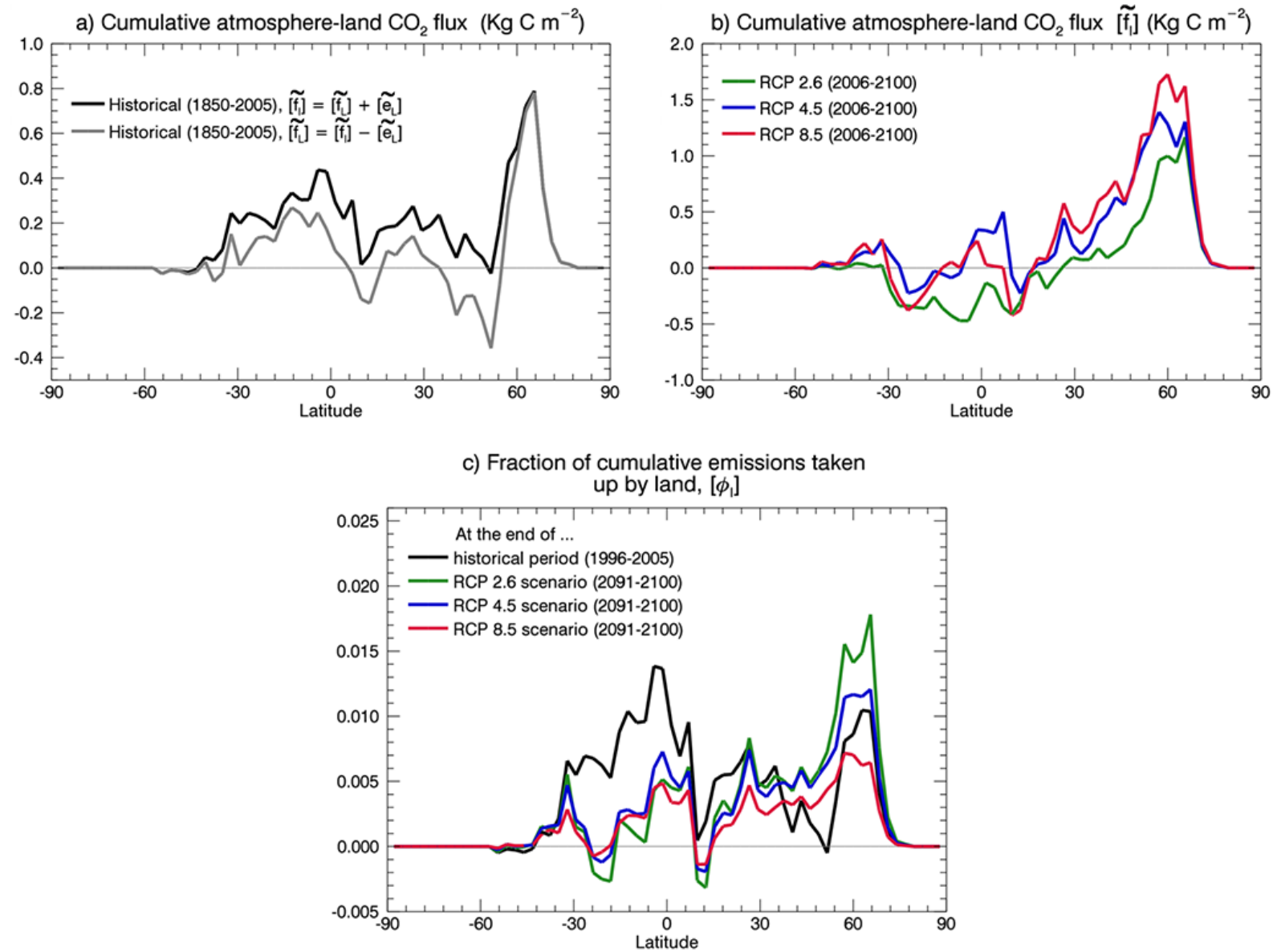

Figure 3. The latitudinal distribution of the cumulative atmosphere-land $\mathrm{CO}_{2}$ fluxes for the historical 1850-2005 (a) and future 2006-2100 (b) periods for the three RCP scenarios. (c) Plots $\left[\varphi_{1}\right]$ the latitudinal contribution of $\tilde{f}_{1}$ to $\Phi_{1}$ the global fraction of cumulative emissions taken up by land over the historical period and over the 21 st century for the three RCP scenarios.

effect is weakest in the RCP 2.6 scenario. This pattern of cumulative atmosphere-land $\mathrm{CO}_{2}$ exchange is broadly similar to that simulated by other ESMs participating in the CMIP5 intercomparison. For example, Fig. 2 of Koven (2013) compares changes in land carbon over the 2040-2060 period for the RCP 4.5 scenario from five ESMs including CanESM2. $\mathrm{He}$ finds that most ESMs lose carbon to the atmosphere in the tropics and gain carbon from the atmosphere in mid- to high-latitude land regions.

Figure $3 \mathrm{c}$ plots $\left[\varphi_{1}\right]$ the latitudinal distribution of the contribution to $\Phi_{1}$, the fraction of cumulative anthropogenic emissions taken up by land, for the historical period and for the three climate change scenarios. Comparison of Fig. 3b and $\mathrm{c}$ for the three climate change scenarios indicates that while the highest atmosphere-land carbon fluxes $\left[\tilde{f}_{1}\right]$ occur at mid- to high-latitude regions in the RCP 8.5 scenario, the fraction of cumulative anthropogenic emissions taken up by land $\left[\varphi_{1}\right]$ is highest in the RCP 2.6 scenario. The land is unable to sustain the same fractional uptake of emitted carbon in the more strongly forced RCP 8.5 scenario compared to the RCP 2.6 scenario in this region. Figure 3c also shows that the differences in $\left[\varphi_{1}\right]$ among RCPs are largest at high latitudes (between 50 and $70^{\circ} \mathrm{N}$ ) and that the value of $\left[\varphi_{1}\right]$ is similar in the tropics for the three scenarios.

\subsection{Geographical distribution}

Figure 4 displays the simulated geographical distributions of changes in temperature $(\Delta T)$, precipitation $(\Delta P)$ and liquid moisture in the top $1 \mathrm{~m}$ soil layer $(\Delta \theta)$ for the three RCP scenarios during the 21 st century. The changes are calculated as the difference between the decadal averages of the years 2006-2015 and 2091-2100 averaged over the three ensemble members. As expected, temperature changes are larger over land and in polar regions than over oceanic regions (Fig. 4a, $\mathrm{b}$ and $\mathrm{c})$. In the tropics, the temperature increases are comparatively large over the South American continent and the Amazonian region in association with reductions in precipitation (Fig. 4d, e and f). Precipitation decreases over most of the South American region, increases over northern mid- to high-latitude land regions and also over land in the Southeast 


\section{Change over the 2006-2100 period}

calculated as the difference between the decadal averages for the years 2006-2015 and 2091-2100

RCP 2.6

RCP 4.5

RCP 8.5

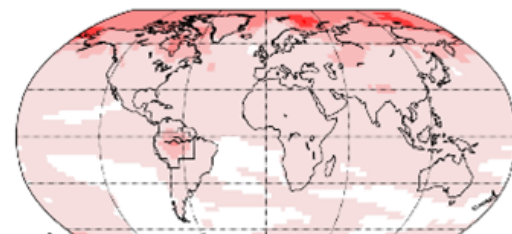

a)

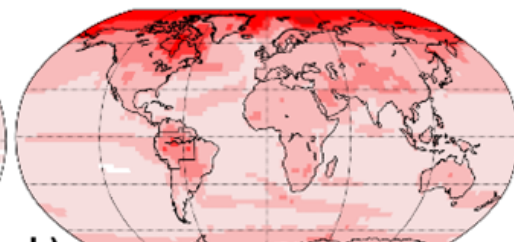

b)

$\Delta \mathrm{T}$ Change in temperature $\left({ }^{\circ} \mathrm{C}\right)$
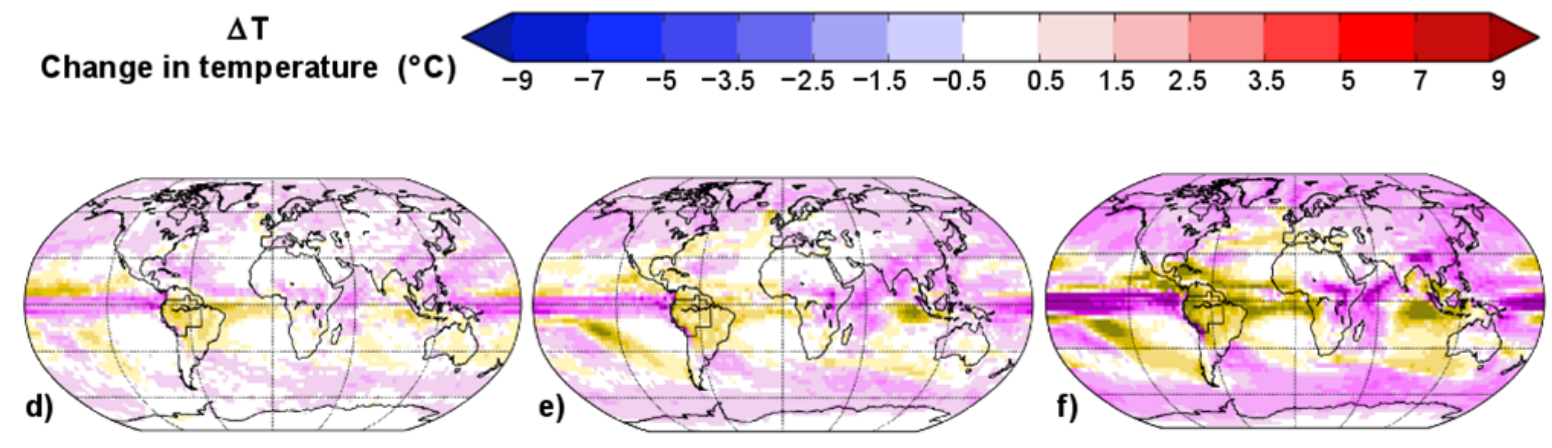

$\Delta \mathbf{P}$

Change in precipitation ( $\mathrm{mm} /$ year)
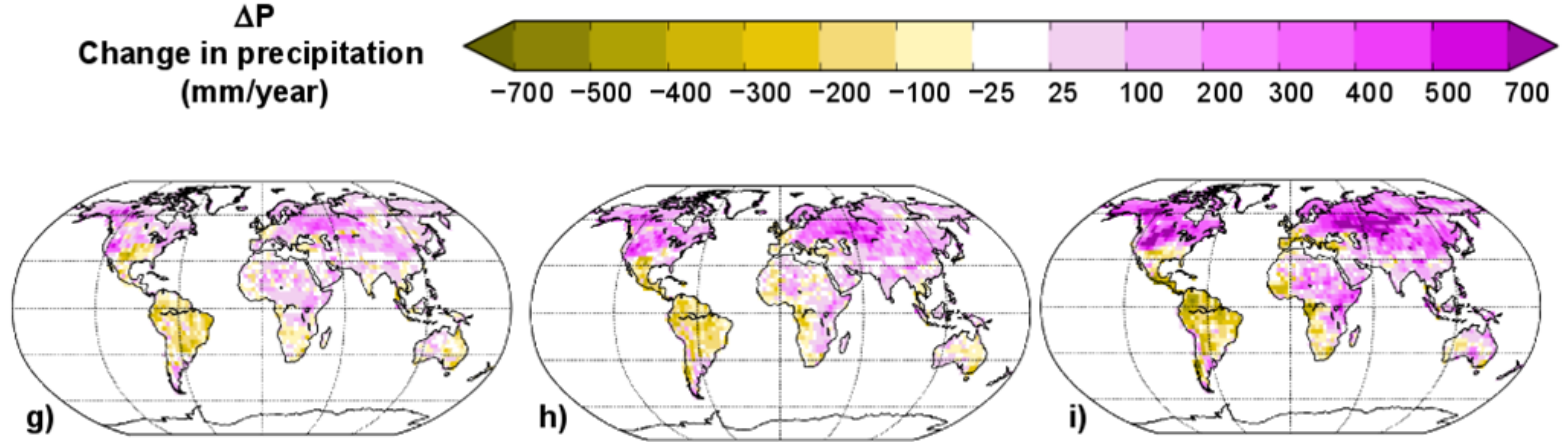

$\Delta \theta$

Change in soil moisture in top $1 \mathrm{~m}$ soil $(\mathrm{mm})$

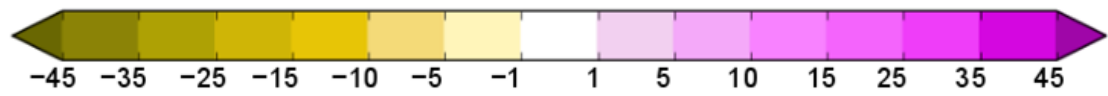

Figure 4. Geographic distribution of changes in temperature $(\Delta T)$, precipitation $(\Delta P)$ and soil moisture in the top $1 \mathrm{~m}$ soil layer $(\Delta \theta)$ over the 2006-2100 period in the three RCP scenarios.

Asian region and parts of central Africa in all scenarios. Soil moisture responds to changes in precipitation with large decreases over the South American continent, in particular the Amazonian region, and increases over mid- to high-latitude land regions (Fig. 4g, $\mathrm{h}$ and i).

The associated changes in vegetation, soil and total land carbon are shown in Fig. 5. Changes in atmospheric $\mathrm{CO}_{2}$ concentration, temperature, precipitation and radiation all affect the changes in carbon uptake and vegetation biomass. Over mid- to high-latitude regions, where vegetation growth is currently limited by temperature, vegetation biomass increases and $\Delta h_{\mathrm{V}}$ is positive (Fig. $5 \mathrm{a}, \mathrm{b}$ and c) both because of increases in temperature and because of the $\mathrm{CO}_{2}$ fertil- ization effect. In the tropics, carbon uptake is primarily limited by precipitation and higher $\mathrm{CO}_{2}$ levels cannot increase vegetation biomass if soil moisture levels limit photosynthesis. Vegetation biomass increases over the Southeast Asian region and central Africa in the RCP 4.5 and 8.5 scenarios where precipitation and soil moisture also increase implying that, in a broad sense, carbon uptake by vegetation is not soil moisture limited. Vegetation biomass increases in the central African region (Fig. 5a, b and c) despite the decrease the precipitation (Fig. 4d, e and f) and soil moisture (Fig. 4g, h and i) in the central-west of this area. Soil moisture stress for photosynthesis in CTEM, the terrestrial carbon cycle component of CanESM2, is modelled as a function of soil matrix 


\section{Change over the 2006-2100 period}

calculated as the difference between the decadal averages for the years 2006-2015 and 2091-2100
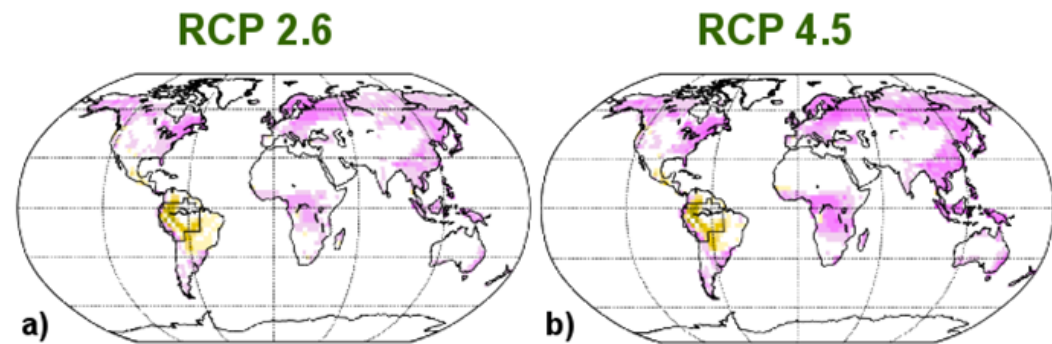

b)

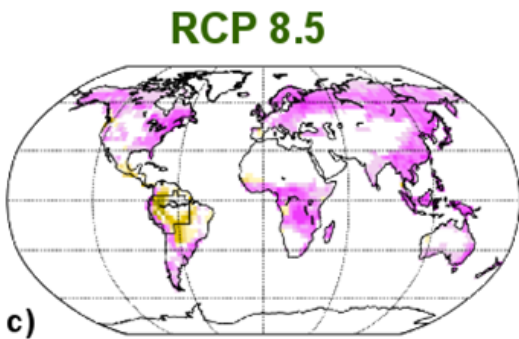

$\Delta \mathbf{h}_{\mathrm{v}}$

Change in vegetation biomass density $\left(\mathrm{Kg} \mathrm{C} / \mathrm{m}^{2}\right)$
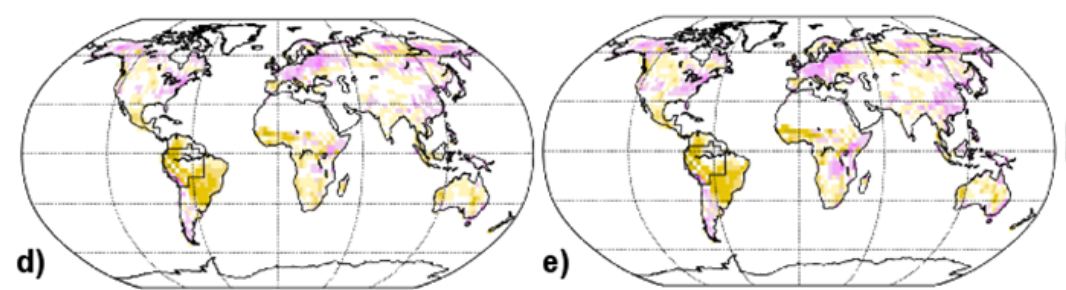

$\Delta \mathbf{h}_{\mathrm{s}}$

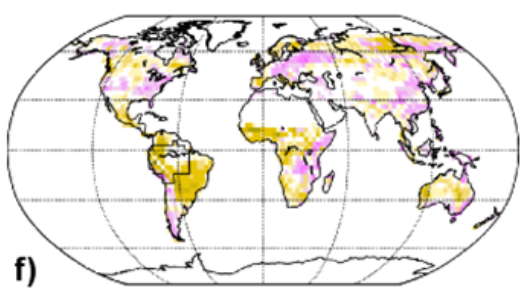

Change in soil and litter carbon mass density $\left(\mathrm{Kg} \mathrm{C} / \mathrm{m}^{2}\right)$

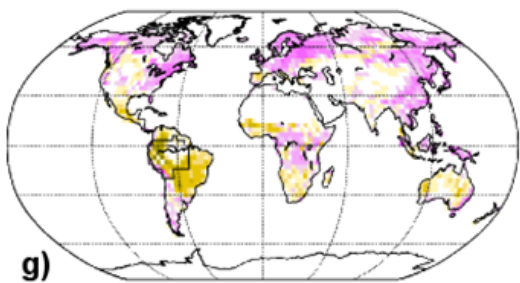

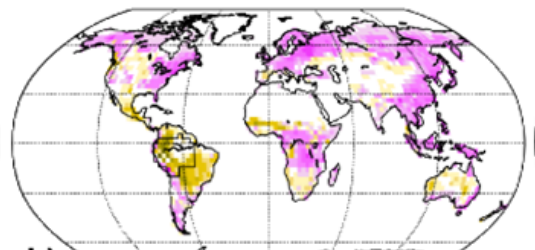

h)

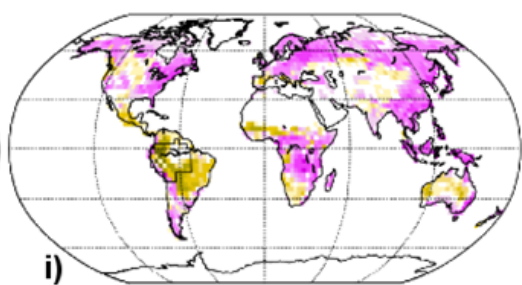

$\Delta \mathbf{h}_{1}$

Change in total land carbon density $\left(\mathrm{Kg} \mathrm{C} / \mathrm{m}^{2}\right)$

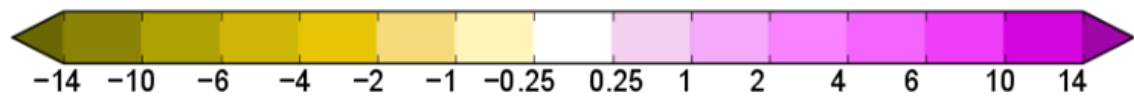

Figure 5. Geographic distribution of changes in vegetation biomass $\left(\Delta h_{\mathrm{V}}\right)$, soil plus litter carbon $\left(\Delta h_{\mathrm{S}}\right)$ and total land carbon $\left(\Delta h_{\mathrm{L}}=\right.$ $\Delta h_{\mathrm{V}}+\Delta h_{\mathrm{S}}$ ) over the 2006-2100 period in the three RCP scenarios.

potential which depends on the absolute soil moisture. Depending on the absolute initial value of soil moisture in a region and given the increasing $\mathrm{CO}_{2}$, photosynthesis may or may not reduce for small reductions in soil moisture. The reduction in precipitation and soil moisture over tropical and subtropical South America, including the Amazonian region, leads to reduced vegetation biomass in all scenarios. Here the benefits of the $\mathrm{CO}_{2}$ fertilization effect are not realized due to large reductions in precipitation and soil moisture. The loss of carbon over the South American continent is compensated differently by the gains over other tropical regions in the three scenarios. As a result, cumulatively over the 20062100 period, the tropics lose carbon in the RCP 2.6 scenario but remain near neutral in the RCP 4.5 and 8.5 scenarios as seen earlier in Fig. $3 b$.

The simulated changes in soil and litter carbon $\Delta h_{\mathrm{S}}$ (Fig. 5d, e and f) are generally smaller than the changes in vegetation biomass, as also seen in the global values of Fig. 1, except over tropical and subtropical South America. Midto high-latitude regions see both increases and decreases in soil carbon depending on whether increased carbon inputs into the soil through increased litter fall (via increases in NPP) are compensated by increased respiration (associated with warmer temperatures) or not. Tropical ecosystems of South America and Africa, except in regions of increased precipitation, typically lose soil carbon in these simulations. 
The decrease in soil carbon over the South American continent is caused primarily by reduced litter fall inputs into the soil, which occur as a result of reduced NPP associated with reductions in precipitation and soil moisture. The net result, in terms of changes in total land carbon $\Delta h_{\mathrm{L}}=$ $\Delta h_{\mathrm{V}}+\Delta h_{\mathrm{S}}$ (last row of Fig. 5), is that while mid- to highlatitude and central African terrestrial ecosystems sequester carbon, South American ecosystems become a carbon source in all scenarios.

Figure 6 displays the geographical distribution of the "reactivity" $\vartheta$ of land carbon to future climate change based on Eq. (9). Reactivity in this context refers to sensitivity of land carbon change, over the 2006-2100 period, to the different climate change scenarios. At least three large-scale regions stand out in Fig. 6. The mid to northern part of the South American continent, including the Amazonian region, exhibits low reactivity, the central African region exhibits high reactivity, and the northeastern Eurasian region including the Scandinavian countries exhibit low reactivity to climate change scenarios. The tropical forests of Southeast Asia and southeastern China also exhibit high reactivity. Regions of low reactivity indicate similar land carbon change across scenarios. One reason for this is the compensatory effects of forcings, as discussed in the next section for the Amazonian region, where the positive effects of increased $\mathrm{CO}_{2}$ fertilization effect are counteracted by the negative effects of higher reduction in precipitation with increasing $\mathrm{CO}_{2}$. Arid regions with generally low vegetation are also expected to exhibit low reactivity because regardless of the atmospheric $\mathrm{CO}_{2}$ concentration, the land carbon amount is not expected to change substantially. This is the case for the Sahara region, parts of Australia, the arid region in northwestern China and the adjacent Gobi desert. Regions of high reactivity indicate different land carbon change across scenarios. In these regions the compensatory effects of forcings are absent. These regions include the Central African region, and tropical forests of Southeast Asia and southeastern China. Here, increasing atmospheric $\mathrm{CO}_{2}$ concentration, unlike the regions over the South American continent, does not cause large decrease in precipitation and the benefits of $\mathrm{CO}_{2}$ fertilization are realized giving different land carbon change in the three scenarios.

\subsection{The Amazonian and central African regions}

Figure 7a plots the simulated land carbon change $\Delta H_{\mathrm{L}}=\tilde{F}_{\mathrm{L}}$ over the low reactivity Amazonian region (we use the region as defined by the Amazon River basin in the model) for the historical (1900-2005) and future (2006-2100) periods. The region initially takes up carbon during the 1900-1950 period and is near neutral for the 1950-1980 period. Houghton et al. (2009) summarize the regional carbon budget using results from inversion-based studies and plot-based biomass measurements and indicate that Amazonia has been, on average, carbon neutral over the 1990s albeit a small source of at-

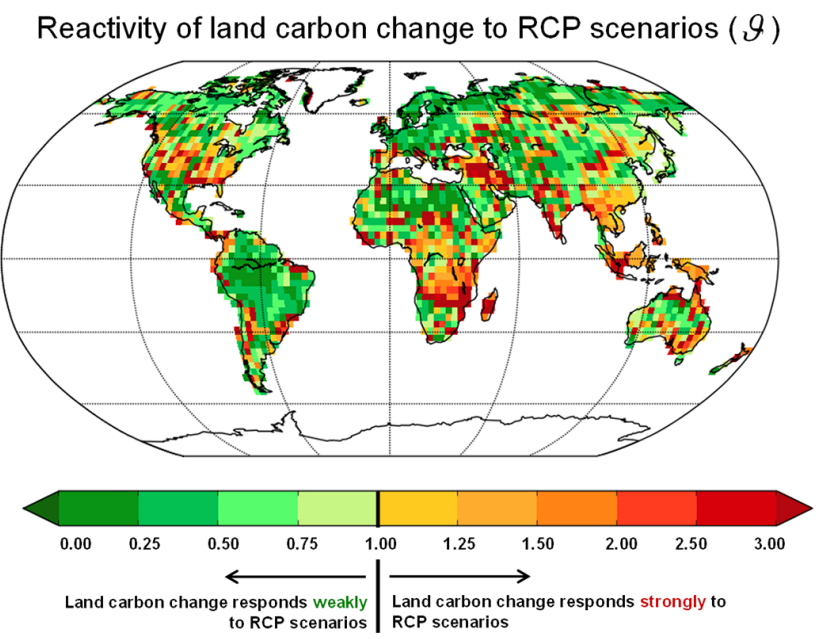

Figure 6. Geographical distribution of the reactivity $(\vartheta)$ of land carbon change to future climate change scenarios calculated from Eq. (9). Values less than 1 (green tones) indicate comparatively weak dependence on scenario and values greater than 1 (orange and red tones) indicate strong dependence on scenario.

mospheric carbon during El Niño events. Malhi (2010), who summarizes inventory, remotely sensed and inversion-based estimates, calculates tropical American biomes as a whole to be a weak sink of atmospheric carbon of $0.086 \pm 0.15$ $\mathrm{Pg} \mathrm{C} \mathrm{yr}^{-1}$ for the period 1990-2006 (his Table 4). From 1980 onwards, as land carbon decreases, CanESM2 simulates the region to be a growing source of carbon to the atmosphere.

The Amazonian region is simulated to lose about $20 \mathrm{Pg} \mathrm{C}$ over the 2006-2100 period in all scenarios (Fig. 7a). Although the three scenarios are characterized by quite different $\mathrm{CO}_{2}$ concentrations (Fig. 1a) the carbon losses are similar and the region displays low carbon reactivity to climate change scenarios as seen in Fig. 6. Here the effect of $\mathrm{CO}_{2}$ fertilization associated with increasing $\mathrm{CO}_{2}$ is counteracted by the effects of decreasing precipitation and warming temperatures in the region. As a consequence, the low $\mathrm{CO}_{2} \mathrm{RCP} 2.6$ scenario exhibits nearly as much carbon loss as the high $\mathrm{CO}_{2}$ RCP 8.5 scenario. The simulated loss of land carbon for the region is very similar for the three scenarios in Fig. 7a.

Figure $7 \mathrm{~b}$ displays the simulated change in land carbon over the central African region for the historical (1900-2005) and future (2006-2100) periods. Land carbon increases during the 20th century, hence is a modest sink of atmospheric carbon, with a simulated net land-atmosphere $\mathrm{CO}_{2}$ flux of about $0.06 \mathrm{Pg} \mathrm{C} \mathrm{yr}^{-1}$ for the period 1990-2005. Malhi (2010) estimates that African tropical biomes were a sink of atmospheric carbon of around $0.17 \pm 0.15 \mathrm{PgC} \mathrm{yr}^{-1}$ for the period 1990-2005. The region is simulated to continue to take up $\mathrm{CO}_{2}$ and to act as a sink of atmospheric carbon during the 21 st century with the largest carbon uptake for the RCP 8.5 scenario. Unlike the Amazonian region for which precipitation and soil moisture decrease as $\mathrm{CO}_{2}$ increases (Fig. $4 \mathrm{~g}$, $\mathrm{h}$ 
a) Land carbon change in the Amazonian region

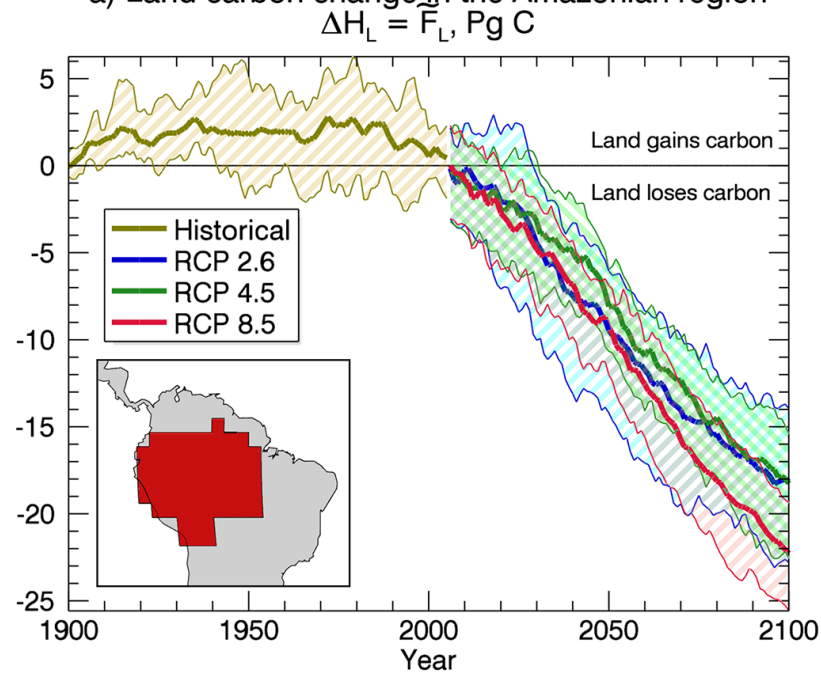

b) Land carbon change in the central African region

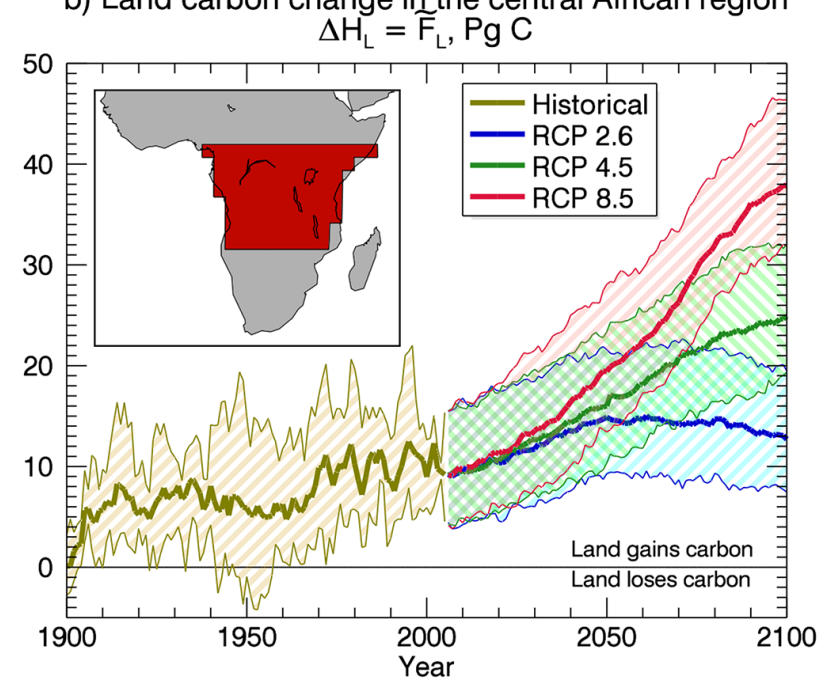

Figure 7. Simulated change in land carbon $\left(\Delta H_{\mathrm{L}}=\tilde{F}_{\mathrm{L}}\right)$ over the Amazonian (a) and central African (b) regions (outlined in the inset) for the historical (1900-2005) and future (2006-2100) periods. The future results are from the three RCP scenarios. The shading in light beige, blue, green and red colours corresponds to the range across the three ensemble members of the historical and RCP 2.6, 4.5 and 8.5 simulations, respectively.

and i), precipitation and soil moisture increase in the central African region in all scenarios. As a result, photosynthesis is not soil moisture limited and the benefits of the $\mathrm{CO}_{2}$ fertilization effect are realized. The change in land carbon in the region shows large reactivity to climate change scenarios consistent with large values of $\vartheta$ in Fig. 6 .

\section{Discussion and conclusions}

ESMs are able to simulate the broad geographical and latitudinal patterns of atmosphere-land $\mathrm{CO}_{2}$ exchange but are not expected to simulate small-scale patterns. Biases in simulated climate, the pre-industrial land carbon state, the strength of the $\mathrm{CO}_{2}$ fertilization effect, and the differences in the manner in which LUC is represented in models all contribute to uncertainties in simulated atmosphere-land $\mathrm{CO}_{2}$ fluxes. The terrestrial carbon cycle modelling community can only broadly quantify the contributions of climate change, $\mathrm{CO}_{2}$ fertilization, LUC and nitrogen deposition to the cumulative atmosphere-land $\mathrm{CO}_{2}$ flux over the historical period. Uncertainties remain in the magnitude of the $\mathrm{CO}_{2}$ fertilization effect (Arora et al., 2013) and LUC emissions (Ramankutty et al., 2007), and differences exist in the manner in which LUC is represented in ESMs (Brovkin et al., 2013). The representation of coupled carbon and nitrogen cycles over land in ESMs is being developed and a few ESMs couple terrestrial carbon and nitrogen cycles and thus have the ability to treat nitrogen deposition. Arora et al. (2013) show that the behaviour of models that include this coupling differs from models that do not and large uncertainties remain in the manner in which nitrogen limitation constrains the $\mathrm{CO}_{2}$ fertilization effect (see also Thomas et al., 2013). Finally, high northern latitude peatlands and the carbon losses typically expected with the degradation of permafrost soils are not represented in any of the ESMs participating in CMIP5, including CanESM2.

Despite these caveats, CanESM2 is able to simulate broadscale patterns of historical atmosphere-land $\mathrm{CO}_{2}$ flux that are consistent with observation-based estimates. These estimates indicate that, at present, the tropics are either a weak source of atmospheric carbon or near neutral while mid- to high-latitude northern land is gaining carbon from the atmosphere. Two main conclusions can be drawn from CanESM2 results which simulate the terrestrial biosphere's response to potential future changes in climate and atmospheric $\mathrm{CO}_{2}$ concentration: the relative role of the land in providing an atmospheric carbon removal service will decline, and further increases in atmospheric $\mathrm{CO}_{2}$ concentration will lead to a strengthening of the sink of atmospheric carbon in midto high-latitude regions while, overall, the tropics will become either a modest source of carbon to the atmosphere or stay near neutral. Within the tropics, the Amazonian region is simulated to be a net source of carbon for the atmosphere during the 21 st century, even in the absence of anthropogenic LUC, while the African region is a simulated to be a sink of atmospheric carbon. Over the Amazonian region, a low $\mathrm{CO}_{2}$ pathway, such as the RCP 2.6 scenario, may not give an appreciably different result than a high $\mathrm{CO}_{2}$ pathway, such as the RCP 8.5 scenario. This comparative independence of Amazonian carbon loss across climate scenarios is an unexpected and an apparently novel result. The simulated decrease in precipitation that occurs in conjunction with higher 
atmospheric $\mathrm{CO}_{2}$ concentrations counteracts the $\mathrm{CO}_{2}$ fertilization effect in the region.

The response simulated by CanESM2, and other ESMs, to future changes in atmospheric $\mathrm{CO}_{2}$ depends on the strength of the $\mathrm{CO}_{2}$ fertilization effect of the models' terrestrial carbon cycle components. Boer and Arora (2013) compare the strength of carbon-concentration and carbon-climate feedbacks of land and ocean carbon cycle components in CanESM2 and these methods are also applied to results from eight comprehensive ESMs participating in CMIP5 (including CanESM2) and to an ESM of intermediate complexity in Arora et al. (2013). These results are from idealized simulations in which atmospheric $\mathrm{CO}_{2}$ increases at a rate of $1 \%$ per year until the concentration has quadrupled. The magnitude of the carbon-concentration feedback parameter over land is importantly affected by the strength of the $\mathrm{CO}_{2}$ fertilization effect. The CanESM2 value of this feedback parameter $\beta_{\mathrm{L}}$ is $0.97 \mathrm{Pg} \mathrm{Cppm}^{-1}$ which compares well with the model mean of $0.92 \mathrm{Pg} \mathrm{C} \mathrm{ppm}^{-1}$ from nine models which have values ranging from 0.22 to $1.46 \mathrm{Pg} \mathrm{C} \mathrm{ppm}^{-1}$ (Table 2 of Arora et al., 2013).

The result that the tropics may either become a modest source of carbon to the atmosphere or stay near neutral in the future as atmospheric $\mathrm{CO}_{2}$ concentration increases is consistent with the results of other ESMs as reported in Koven (2013) who compares the simulation results for the RCP 4.5 scenario from five comprehensive ESMs participating in CMIP5. The spatial pattern of carbon losses differs somewhat among participating ESMs because of different biases in simulated climate and different climate change patterns. Our finding that South American ecosystems lose carbon in future simulations is consistent with results reported in Koven (2013) (see his Fig. 2).

Joetzjer et al. (2013) summarize changes in precipitation due to climate change over the Amazonian region from models participating in CMIP3 and CMIP5. They conclude that there is a consensus amongst models on an overall reduction in precipitation and a lengthening of the dry season. This is related to a northward shift of the boreal summer intertropical convergence zone in CMIP5 models, in line with a more asymmetric warming between the Northern and Southern Hemispheres. Joetzjer et al. (2013) also show that present-day simulated precipitation is biased low in CMIP3 and CMIP5 models over the Amazonian region compared to observation-based estimates. This is also the case for CanESM2 as shown in Fig. 8 which compares model precipitation with the observation-based estimate from the CPC Merged Analysis of Precipitation (CMAP) based on Xie and Arkin (1997) for the period 1979-1998.

The low value of simulated precipitation for the current climate makes the modelled carbon balance in the Amazonian region somewhat more vulnerable to a reduction in precipitation than would be the case for the real-world forest. Since the tendency to underestimate precipitation over the Amazonia is common to most climate models (Randall et

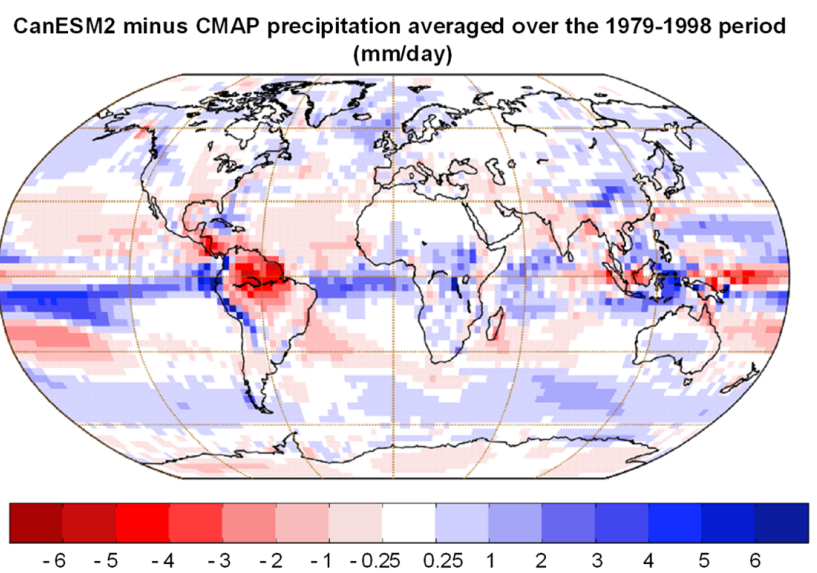

Figure 8. Difference between CanESM2 and observation-based precipitation estimates from CPC Merged Analysis of Precipitation (CMAP) based on Xie and Arkin (1997) averaged over the 19791998 period.

al., 2007, Fig. 8.5; Joetzjer et al., 2013) this caveat will apply to other model results as well. The low precipitation and the resulting comparatively low vegetation biomass and soil carbon is partly the reason that changes in vegetation biomass and soil carbon over the region are simulated to be small during the 21 st century in Fig. 5. Had the modelled precipitation for the 20th century not been biased low we would expect the carbon balance of the region to have transitioned from sink to source in Fig. 7a at a somewhat later date. However, overall carbon losses would also be larger because of the larger carbon stores per unit area.

The absence of high northern latitude peatlands in the models means that the carbon losses expected from the degradation of permafrost soils with climate warming are not represented in the models. Carbon losses from high northern latitude peatlands are not expected to offset the carbon losses from the Amazonian region in the global budget. Including these processes would reduce the high-latitude net atmosphere-land $\mathrm{CO}_{2}$ flux (i.e. less sequestration and smaller value of $f_{1}$ ) by increasing carbon losses from soils (i.e. smaller positive or larger negative $\Delta h_{\mathrm{S}}$ ) but would not be expected to change the carbon sink resulting from changes in vegetation biomass (i.e. $\Delta h_{\mathrm{V}}$ would be expected to remain the same). High-latitude permafrost carbon losses are expected to accelerate climate change due to the associated positive permafrost carbon feedback (MacDougall et al., 2012).

The results obtained here provide some insight into the issue of the dieback of the Amazonian forests. This possibility was noted in an earlier study by Cox et al. (2000) and considered somewhat unlikely at the time. Since then the issue has received considerable attention (Clark et al., 2003; Malhi et al., 2009; Lenton, 2011). The recent 2005 and 2010 Amazonian droughts wiped away a decade of carbon gains $\left(\sim 0.4 \mathrm{Pg} \mathrm{Cyr}^{-1}\right)$ in just two drought episodes (carbon releases of 1.6 and $2.2 \mathrm{PgC}$ in 2005 and 2010, respectively) 
according to Lewis et al. (2011). These authors went so far as to suggest that the "era of intact Amazon forests buffering the increase in atmospheric $\mathrm{CO}_{2}$ may have passed". Our simulations suggest that Amazonian forests react to a simulated reduction in precipitation in a manner similar to the 2005 and 2010 drought years (Marengo et al., 2008, 2011) when these forests were a net source of carbon.

CanESM2 results for the Amazonian region are also pertinent to the question of the permanence of carbon sequestration realized through a reduction in deforestation. Simulation results suggest that regardless of such efforts terrestrial carbon pools in the Amazonian region would remain vulnerable to the adverse effects of climate change. In addition, a low $\mathrm{CO}_{2}$ pathway may not leave the region any better off, from a carbon perspective, than a high $\mathrm{CO}_{2}$ pathway. Possible future carbon loss from the region has obvious implications for forest structure as well as for policy decisions that promote tropical afforestation programs.

Our results and those from other ESMs reported in Koven (2013) differ from two recent studies which investigate the effect of future climate change in the Amazonian region. The Rammig et al. (2010) and Huntingford et al. (2013) analyses suggest that it is unlikely the region will become a source of atmospheric carbon. Rammig et al. (2010) use the Lund-Potsdam-Jena managed land (LPJmL) terrestrial ecosystem model driven with adjusted data from a number of climate models for the SRES-A1B scenario and find that the region gains carbon from atmosphere when the effect of $\mathrm{CO}_{2}$ fertilization is considered but the reverse is the case if $\mathrm{CO}_{2}$ fertilization is not operating. Huntingford et al. (2013) perform a similar analysis for the SRES-A2 scenario using the TRIFFID ecosystem model of the UK Met Office and find that only one of their 22 simulations results in loss of carbon from the tropical forests of the Americas. The carbon-climate feedback parameter $\beta_{\mathrm{L}}$ of the TRIFFID model $\left(1.16 \mathrm{Pg} \mathrm{C} \mathrm{ppm}^{-1}\right)$ is $26 \%$ higher than that of CTEM (the terrestrial carbon cycle component of CanESM2) (0.92 $\mathrm{Pg} \mathrm{C} \mathrm{ppm}^{-1}$ ) and its $\mathrm{CO}_{2}$ fertilization effect is stronger (Arora et al., 2013). For the LPJ model, Gerber et al. (2004) report that GPP $(G)$ increases from $\sim 135 \mathrm{Pg} \mathrm{Cyr}^{-1}$ to $\sim 159 \mathrm{Pg} \mathrm{Cyr}^{-1}$ as $\mathrm{CO}_{2}$ increases from 280 to $370 \mathrm{ppm}$, which yields a value of $\mathrm{d} G / \mathrm{dCO} \mathrm{O}_{2}$ of $0.27 \mathrm{PgC} \mathrm{yr}^{-1} \mathrm{ppm}^{-1}$. For a historical simulation with no LUC (i.e. no increasing crop area) and with increasing $\mathrm{CO}_{2}$ from 285 to $379 \mathrm{ppm}$ CanESM2/CTEM yield a $\mathrm{d} G / \mathrm{d} C \mathrm{O}_{2}$ of $0.10 \mathrm{Pg} \mathrm{C} \mathrm{yr}^{-1} \mathrm{ppm}^{-1}$ implying that the $\mathrm{CO}_{2}$ fertilization effect in the LPJ model is also stronger than that of CTEM. The weaker $\mathrm{CO}_{2}$ fertilization effect in CTEM and the simulated decrease in precipitation over the Amazonian region together result in a simulated loss of carbon to the atmosphere. The strength of the $\mathrm{CO}_{2}$ fertilization effect in terrestrial ecosystem models is an important uncertainty in determining the future carbon balance of the Amazonian region.

In summary, CanESM2 results for the RCP 2.6, 4.5 and 8.5 scenarios indicate that land acts as an overall sink of at- mospheric carbon with the cumulative fraction of emissions sequestered by land by the year 2100 ranging from 10-20\% depending on scenario. The land is less effective in removing carbon from the atmosphere in these scenarios than was the case during the historical period. The future latitudinal structure of atmosphere-land $\mathrm{CO}_{2}$ flux is similar to that for the recent historical (1980-2005) period with mid- to high-latitude regions gaining carbon from the atmosphere and tropical regions near neutral or a weak carbon source. Different geographic land regions react differently to the changes in $\mathrm{CO}_{2}$ and climate associated with the RCP scenarios and this is quantified by means of a "reactivity" measure for land carbon. The future decrease in land carbon over the Amazonian region, which has received significant attention in the scientific literature, is notably similar across the three RCP scenarios despite their differences. By contrast, land carbon over the central African region displays a strong response to the differences in $\mathrm{CO}_{2}$ and climate change associated with the different scenarios. These large-scale patterns of simulated atmosphere-land $\mathrm{CO}_{2}$ flux provide some insight into the possible ways in which the terrestrial biosphere is likely to respond to future changes in atmospheric $\mathrm{CO}_{2}$ and climate.

Acknowledgements. The authors would like to thank John Scinocca and Nadja Steiner for their comments on an earlier version of this paper. We are also appreciate comments from Kirsten Thonicke and the two reviewers that helped improved this paper.

Edited by: K. Thonicke

The works published in this journal are distributed under the Creative Commons Attribution 3.0 License. This license does not affect the Crown copyright work, which is re-usable under the Open Government Licence (OGL). The Creative Commons Attribution 3.0 License and the OGL are interoperable and do not conflict with, reduce or limit each other.

(ㄷ) Crown copyright 2014

\section{References}

Arora, V. K. and Boer, G. J.: Uncertainties in the 20th century carbon budget associated with land use change, Glob. Change Biol., 16, 3327-3348, 2010.

Arora, V. K., Boer, G. J., Christian, J. R., Curry, C. L., Denman, K. L., Zahariev, K., Flato, G. M., Scinocca, J. F., Merryfield, W. J., and Lee, W. G.: The effect of terrestrial photosynthesis down-regulation on the 20th century carbon budget simulated with the CCCma Earth System Model, J. Climate, 22, 60666088, 2009.

Arora, V. K., Scinocca, J. F., Boer, G. J., Christian, J. R., Denman, K. L., Flato, G. M., Kharin, V. V., Lee, W. G., and Merryfield, W. J.: Carbon emission limits required to satisfy future representative concentration pathways of greenhouse gases, Geophys. Res. Lett., 38, L05805, doi:10.1029/2010GL046270, 2011. 
Arora, V. K., Boer, G. J., Friedlingstein, P., Eby, M., Jones, C. D., Christian, J. R., Bonan, G., Bopp, L., Brovkin, V., Cadule, P., Hajima, T., Ilyina, T., Lindsay, K., Tjiputra, J. F., and Wu, T.: Carbon-concentration and Carbon-climate feedbacks in CMIP5 Earth System Models, J. Climate, 26, 5289-5314, 2013.

Boer, G. J. and Arora, V. K.: Feedbacks in emission-driven and concentration-driven global carbon budgets, J. Climate, 26, 3326-3341, 2013.

Brovkin, V., Boysen, L.,Arora, V. K., Boisier, J. P., Cadule, P., Chini, L., Claussen, M., Friedlingstein, P., Gayler, V., van den Hurk, B. J. J. M., Hurtt, G. C., Jones, C. D., Kato, E., de NobletDucoudré, N., Pacifico, F., Pongratz, J., and Weiss, M.: Effect of anthropogenic land-use and land cover changes on climate and land carbon storage in CMIP5 projections for the 21st century, J. Climate, 26, 6859-6881, 2013.

Canadell, J. G., Le Quéré, C., Raupach, M. R., Field, C. B., Buitenhuis, E. T., Ciais, P., Conway, T. J., Gillett, N. P., Houghton, R. A., and Marland, G.: Contributions to accelerating atmospheric $\mathrm{CO}_{2}$ growth from economic activity carbon intensity, and efficiency of natural sinks, P. Natl. Acad. Sci. USA, 104, 18666-18870, 2007.

Ciais, P., Canadell, J. G., Luyssaert, S., Chevallier, F., Shvidenko, A., Poussi, Z., Jonas, M., Peylin, P., King, A. W., Schulze,E- D., Piao, S., Rodenbeck, C., Peters, W., and Breon, F.M.: Can we reconcile atmospheric estimates of the northern terrestrial carbon sink with land-based accounting?, Curr. Opin. Environ. Sust., 2, 225-230, 2010.

Christian, J. R., Arora, V. K., Boer, G. J., Curry, C. L., Zahariev, K., Denman, K. L., Flato, G. M., Lee, W. G., Merryfield, W. J., Roulet, N. T., and Scinocca, J. F.: The global carbon cycle in the Canadian Earth system model (CanESM1): Preindustrial control simulation, J. Geophys. Res., 115, G03014, doi:10.1029/2008JG000920, 2010.

Clark, D. A., Piper, S. C., Keeling, C. D., and Clark, D. B.: Tropical rain forest tree growth and atmospheric carbon dynamics linked to interannual temperature variation during 1984-2000, P. Natl. Acad. Sci. USA, 100, 5852-5857, 2003.

Cox, P. M., Betts, R. A., Jones, C. D., Spall, S. A., and Totterdell, I. J.: Acceleration of global warming due to carbon-cycle feedbacks in a coupled climate model, Nature, 408, 184-187, 2000.

Denman, K. L., Brasseur, G., Chidthaisong, A., Ciais, P., Cox, P. M., Dickinson, R. E., Hauglustaine, D., Heinze, C., Holland, E., Jacob, D., Lohmann, U., Ramachandran, S., da Silva Dias, P. L., Wofsy, S. C., and Zhang, X.: Couplings between changes in the climate system and biogeochemistry, in: Climate Change 2007: The Physical Science Basis, Contribution of Working Group I to the Fourth Assessment Report of the Intergovernmental Panel on Climate Change, edited by: Solomon, S., Qin, D., Manning, M., Chen, Z., Marquis, M., Averyt, K. B., Tignor, M., and Miller, H. L., Cambridge University Press, Cambridge, UK and New York, NY, USA, 499-588, 2007.

Gerber, S., Joos, F., and Prentice, I. C.: Sensitivity of a dynamic global vegetation model to climate and atmospheric $\mathrm{CO}_{2}$, Glob. Change Biol., 10, 1223-1239, 2004.

Houghton, R. A.: Carbon flux to the atmosphere from land-use changes: 1850-2005, in: TRENDS: A Compendium of Data on Global Change, Carbon Dioxide Information Analysis Center,
Oak Ridge National Laboratory, US Department of Energy, Oak Ridge, Tenn., USA, 2008.

Houghton, R., Gloor, M., Lloyd, J., and Potter, C.: The regional carbon budget, in: Amazonia and Global Change, Geophys. Monogr. Ser., vol. 186, edited by: Keller, M., Bustamante, M., Gash, J., and Silva Dias, P., AGU, Washington, DC, 409-428, doi:10.1029/2008GM000718, 2009.

Huntingford, C., Zelazowski, P., Galbraith, D., M Mercado, L., Sitch, S., Fisher, R., Lomas, M., Walker,P, A., Jones, C. D., Booth, B. B., Malhi, Y., Hemming, D., Kay, G., Good, P., Lewis, S. L., Phillips,L, O., Atkin, O. K., Lloyd, J., Gloor, E., Zaragoza-Castells, J., Meir, P., Betts, R., Harris, P., Nobre, C., Marengo, J., and Cox, P. M.: Simulated resilience of tropical rainforests to $\mathrm{CO}_{2}$-induced climate change, Nat. Geosci., 6, 268273, 2013.

Joetzjer, E., Douville, H., Delire, C., and Ciais, P.: Present-day and future Amazonian precipitation in global climate models: CMIP5 vs. CMIP3, Clim. Dynam., 41, 2921-2936, doi:10.1007/s00382012-1644-1, 2013.

Koven, C. D.: Boreal carbon loss due to poleward shift in lowcarbon ecosystems, Nat. Geosci., 6, 452-456, 2013.

Lenton, T. M.: Early warning of climate tipping points, Nat. Clim. Change, 1, 201-209, 2011.

Le Quéré, C., Andres, R. J., Boden, T., Conway, T., Houghton, R. A., House, J. I., Marland, G., Peters, G. P., van der Werf, G. R., Ahlström, A., Andrew, R. M., Bopp, L., Canadell, J. G., Ciais, P., Doney, S. C., Enright, C., Friedlingstein, P., Huntingford, C., Jain, A. K., Jourdain, C., Kato, E., Keeling, R. F., Klein Goldewijk, K., Levis, S., Levy, P., Lomas, M., Poulter, B., Raupach, M. R., Schwinger, J., Sitch, S., Stocker, B. D., Viovy, N., Zaehle, S., and Zeng, N.: The global carbon budget 1959-2011, Earth Syst. Sci. Data, 5, 165-185, doi:10.5194/essd-5-165-2013, 2013.

Lewis, S. L., Brando, P. M., Phillips, O. L., van der Heijden, G. M. F., and Nepstad, D.: The 2010 Amazon drought, Science, 6017, 554, doi:10.1126/science.1200807, 2011.

MacDougall, A. H., Avis, C. A., and Weaver, A. J.: Significant contribution to climate warming from the permafrost carbon feedback, Nat. Geosci., 5, 719-721, 2012.

Malhi, Y.: The carbon balance of tropical forest regions, 19902005, Curr. Opin. Sust. Sci., 2, 4, 237-244, 2010.

Malhi, Y., Aragão, L. E. O. C., Galbraith, D., Huntingford, C., Fisher, R., Zelazowski, P., Sitch, S., McSweeney, C., and Meir, P.: Exploring the likelihood and mechanism of a climatechange-induced dieback of the Amazon rainforest, P. Natl. Acad. Sci. USA, 106, 20610-20615, 2009.

Marengo, J. A., Nobre, C. A., Tomasella, J., Oyama, M. D., Sampaio de Oliveira, G., de Oliveira, R., Camargo, H., Alves, L. M., and Brown, I. F.: The drought of Amazonia in 2005, J. Climate, 21, 495-516, 2008.

Marengo, J. A., Tomasella, J., Alves, L. M., Soares, W. R., and Rodriguez, D. A.: The drought of 2010 in the context of historical droughts in the Amazon region, Geophys. Res. Lett., 38, L12703, doi:10.1029/2011GL047436, 2011.

Moss, R. H., Edmonds, J. A., Hibbard, K. A., Manning, M. R., Rose, S. K., van Vuuren, D. P., Carter, T. R., Emori, S., Kainuma, M., Kram, T., Meehl, G. A., Mitchell, J. F. B., Nakicenovic, N., Riahi, K., Smith, S. J., Stouffer, R. J., Thomson, A. M., Weyant, J. P., 
and Wilbanks, T. J.: The next generation of scenarios for climate change research and assessment, Nature, 463, 747-756, 2010.

Pan, Y., Birdsey, R. A., Fang, J., Houghton, R., Kauppi, P. E., Kurz, W. A., Phillips, O. L., Shvidenko, A., Lewis, S. L., Canadell, J. G., Ciais, P., Jackson, R. B., Pacala, S. W., McGuire, A. D., Piao, S., Rautiainen, A., Sitch, S., and Hayes, D.: A large and persistent carbon sink in the world's forests, Science, 333, 988-993, 2011.

Randall, D. A., Wood, R. A., Bony, S., Colman, R., Fichefet, T., Fyfe, J., Kattsov, V., Pitman, A., Shukla, J., Srinivasan, J., Stouffer, R. J., Sumi A., and Taylor, K. E.: Cilmate models and their evaluation, in: Climate Change 2007: The Physical Science Basis. Contribution of Working Group I to the Fourth Assessment Report of the Intergovernmental Panel on Climate Change, edited by: Solomon, S., Qin, D., Manning, M., Chen, Z., Marquis, M., Averyt, K. B., Tignor, M., and Miller, H. L., Cambridge University Press, Cambridge, UK and New York, NY, USA, 589-662, 2007.

Ramankutty, N., Gibbs, H. K., Archard, F., DeFries, R., Foley, J. A., and Houghton, R. A.: Challenges to estimating carbon emissions from tropical deforestation, Glob. Change Biol., 13, 51-66, 2007.
Rammig, A., Jupp, T. E., Thonicke, K., Tietjen, B., Heinke, J., Ostberg, S., Lucht, W., Cramer, W., and Cox, P. M.: Estimating the risk of Amazonian forest dieback, New Phytol., 187, 694-706, 2010.

Scinocca, J. F., McFarlane, N. A., Lazare, M., Li, J., and Plummer, D.: Technical Note: The CCCma third generation AGCM and its extension into the middle atmosphere, Atmos. Chem. Phys., 8, 7055-7074, doi:10.5194/acp-8-7055-2008, 2008.

Taylor, K. E., Stouffer, R. J., and Meehl, G. A.: An Overview of CMIP5 and the Experiment Design, B. Am. Meteorol. Soc., 93, 485-498, 2012.

Thomas, R. Q., Zaehle, S., Templer, P. H., and Goodale, C. L.: Global patterns of nitrogen limitation: confronting two global biogeochemical models with observations, Glob. Change Biol., 19, 2986-2998, doi:10.1111/gcb.12281, 2013.

Xie, P. and Arkin, P. A.: Global Precipitation: A 17-Year Monthly Analysis Based on Gauge Observations, Satellite Estimates, and Numerical Model Outputs, B. Am. Meteorol. Soc., 78, 25392558, 1997. 